\title{
A Rapidly Growing Subepithelial Mass in the Stomach
}

\author{
Ayoung Lee, Soo-Jeong Cho
}

Department of Internal Medicine and Liver Research Institute, Seoul National University College of Medicine, Seoul, Korea

Question: A 58-year old man visited our hospital for poor oral intake after treatment of gastric ulcer with Helicobacter pylori infection. He had weight loss of $5 \mathrm{~kg}$ within 1 month and abdominal discomfort. He had been treated with proton pump inhibitors (PPIs; ilaprazole $10 \mathrm{mg}$ daily) for 2 months with a history of benign gastric ulcer at a previously-visiting hospital. He was diagnosed with pulmonary tuberculosis and cured after the 6 months' medication 40 years ago. He was a current smoker with 40 pack-year. Initial upper endoscopy revealed a focal wall thickening in the gastric fundus (Fig. 1A). Follow-up upper endoscopy after 1-month interval showed a protruding mass-like lesion with intact overlying mucosa (Fig. 1B). The total duration of PPI treatment was 3 months at the time of follow-up endoscopy. On EUS, a 33-mm-sized ill-defined hypoechoic lesion originating mainly from the deep mucosal layer (Fig. 1C).

What is the most likely diagnosis?

Answer: Histopathologically, endoscopic biopsy showed chronic active gastritis with parietal cell hyperplasia without evidence of malignancy (Fig. 2). Gastric parietal cell hyperplasia is a pathologic finding due to protrusion of parietal cells in the lumen of the oxyntic glands in the upper gastrointestinal tract after chronic PPI use. ${ }^{1}$ PPI use can cause various degrees of acid suppression depending on dose, duration and individual responses. The response to inhibit acid production and resulting hypergastrinemia may be intended as a compensating mechanism to stimulate and activate hyperplastic reaction in the oxyntic gland's components to produce more acid, which result in hyperplasia of parietal cells and endochromaffin-like
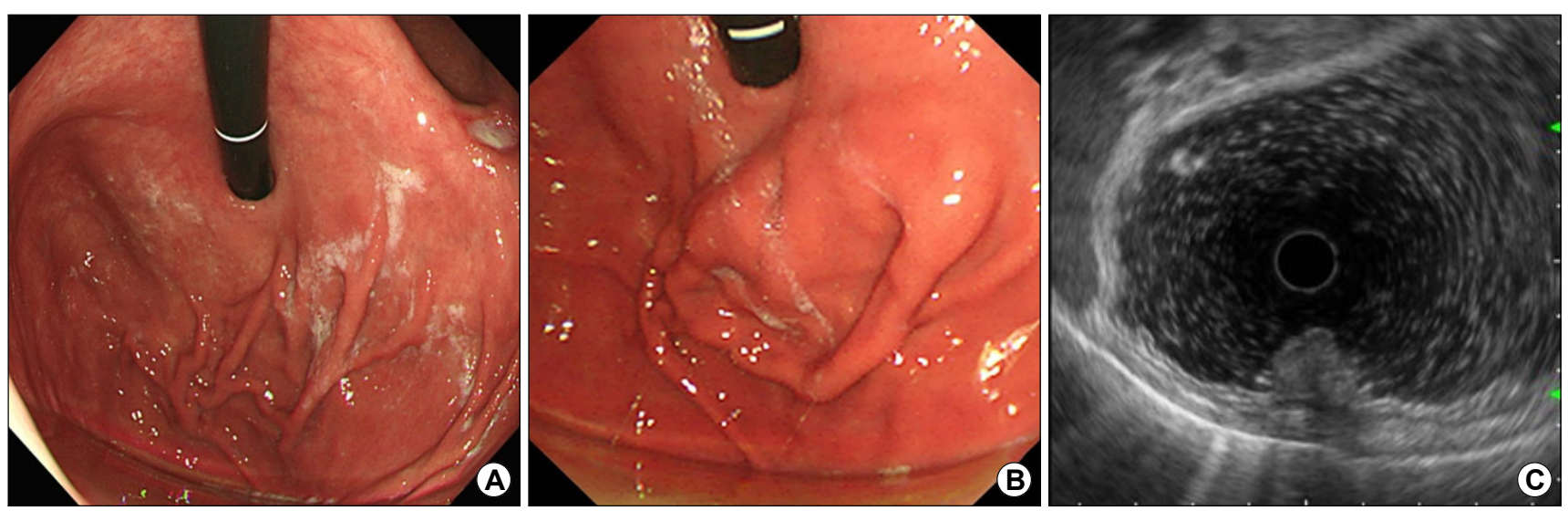

Fig. 1. (A) Endoscopic image after 2 months' use of proton pump inhibitors. (B) A 3.5-cm-sized protruding lesion with intact overlying mucosa at the gastric fundus after 1 month from (A). (C) EUS image showing a 33-mm-sized hypoechoic lesion arising from the deep mucosal layer.

Received: February 5, 2020 Revised: March 8, 2020 Accepted: March 22, 2020

Comesponding author: Soo-Jeong Cho

Department of Internal Medicine and Liver Research Institute, Seoul National

University College of Medicine, 103 Daehak-ro, Jongno-gu, Seoul 03080, Korea

Tel: +82-2-2072-4073, Fax: +82-2-762-9662, E-mail: crystal522@daum.net

Copyright $\odot 2020$ Korean College of Helicobacter and Upper Gastrointestinal Research

(a) The Korean Journal of Helicobacter and Upper Gastrointestinal Research is an Open-Access Journal. All articles are distributed under the terms of the Creative Commons Attribution Non-Commercial License (http:// creativecommons.org/licenses/by-nc/4.0) which permits unrestricted non-commercial use, distribution, and reproduction in any medium, provided the original work is properly cited. 


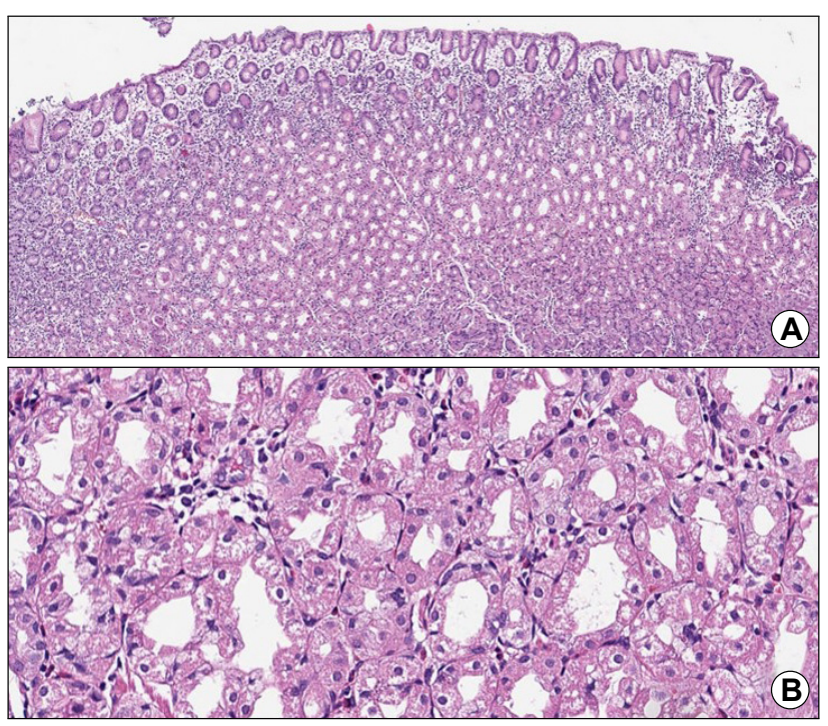

Fig. 2. Endoscopic biopsy results. (A, B) The number of oxyntic glands has increased, and a parietal cell protrusion is observed in each oxyntic gland $(\mathrm{A}: \mathrm{H} \& \mathrm{E}, \times 10 ; \mathrm{B}: \mathrm{H} \& \mathrm{E}, \times 100)$.

cells. ${ }^{2}$ How long it takes to develop parietal cell hyperplasia after use of PPI is unknown.

Endoscopically, gastric parietal cell hyperplasia manifests sporadic fundic polyps, cracked-mucosal change, or cobblestone-like changes of the gastric mucosa. ${ }^{1,3}$ The most common location of the proliferative changes in the mucosa is gastric body and fundus. ${ }^{1}$ It can be missed from a differential diagnosis, because of a relatively low incidence of gastric parietal cell hyperplasia, insufficient history of medication use and atypical endoscopic findings.
Although the gastric parietal cell hyperplasia is reportedly to be associated with chronic PPI use, pathophysiology and clinical significance remain unknown. However, endoscopists need to know the endoscopic findings of the gastric parietal cell hyperplasia to differentiate other upper gastrointestinal tract abnormalities.

\section{CONFLICT OF INTEREST}

No potential conflict of interest relevant to this article was reported.

\section{ORCID}

Ayoung Lee
Soo-Jeong Cho https://orcid.org/0000-0002-0692-8200

\section{REFERENCES}

1. Camilo SM, Almeida ÉC, Miranzi BA, Silva JC, Nomelini RS, Etchebehere RM. Endoscopic and histopathologic gastric changes in chronic users of proton-pump inhibitors. Arq Gastroenterol 2015;52:59-64.

2. Malfertheiner P, Kandulski A, Venerito M. Proton-pump inhibitors: understanding the complications and risks. Nat Rev Gastroenterol Hepatol 2017;14:697-710.

3. Kato M, Miyamoto S. Proton pump inhibitor-associated mucosal change. Intern Med 2017;56:2697. 